\title{
New Species of Monstera (Araceae) from French Guiana
}

\author{
Thomas B. Croat ${ }^{1}$, Joep Moonen ${ }^{2} \&$ Odile Poncy $^{3}$
}

\begin{abstract}
(New species of Monstera (Araceae) from French Guiana) A new species of Monstera, M. barrieri Croat, Moonen \& Poncy, is described from French Guiana. The species is characterized by its deeply pinnately lobed, black-drying blades and the wine-red to orange spadix axis.

Key-words: French Guiana, Monstera, new species.

\section{Resumo}

(Uma nova espécie de Monstera (Araceae) da Guiana Francesa) O presente trabalho apresenta uma nova espécie de Monstera nativa da Guiana Francesa, M. barrieri Croat, Moonen \& Poncy. A espécie é caracterizada por apresentar lâmina profundamente lobada, tornando-se negra quando seca e eixo da espádice vermelho-vináceo a alaranjado.
\end{abstract}

Palavras-chave: Guiana Francesa, Monstera, espécie nova.

\section{INTRODUCTION}

The genus Monstera was last revised by Michael Madison as a Ph.D. dissertation at Harvard University (Madison 1977). This treatment contained a total of 22 species. Subsequently, four species were described from Central America by Grayum (1997), one by Grayum (in Croat \& Grayum, loc. cit.), one by Croat \& Acebey from Bolivia (Croat $\&$ Acebey 2005), and one (Mora \& Croat 2004) from Cabo Corrientes in Chocó Department of Colombia. In addition, one species, M. standleyana G. S. Bunting, was resurrected by Grayum (2003), and another was transferred from Rhodospatha ( $M$. costaricensis (Engl.) Croat \& Grayum (Grayum 1997)) to bring the number of recognized Monstera species to 31. Monstera bolivana Rusby and M. expilata Schott, both species synonymized with M. obliqua Miq. by Madison (1977), are now considered distinct species by the first author and will be formally resurrected as distinct species so that the total will be at least 33. In addition, a number of undescribed species remain in Central and especially South America so that in all probability the total number of species in the genus will approach 60 species.
Here a very distinctive species from French Guiana is described as new. This species was discovered about ten years ago by Joep Moonen who has had it in cultivation at Emerald Jungle Village in French Guiana and was independently rediscovered and recognized as a new species recently in the area of the type locality by Odile Poncy at the Paris Herbarium, Paris, France. However, the species was first collected more than 23 years ago by Serge Barrier and Christian Feuillet. The species is named in honor of Serge Barrier.

\begin{abstract}
Monstera barrieri Croat, Moonen, \& Poncy, sp. nov. Type: French Guiana. Fleuve Approuague, Rivier Arataye, Sauts Parare, Feb. 1981, S. Barrier \& C. Feuillet 2719 (holotype $\mathrm{P}$; isotypes $\mathrm{K}, \mathrm{MO}, \mathrm{NY}, \mathrm{U}$ ).

Fig. 1 a-d.

Planta hemiepiphytica usque ad $10 \mathrm{~m}$ supra terram crescens. Internodia adulta brevia, ca. $2 \mathrm{~cm}$ diam. Folia juvenalia patentia, petiolo $2-2.5 \mathrm{~cm}$ longo, lamina anguste oblongo-lanceolata $5.5-8 \mathrm{~cm}$ longa. Folia adulta petiolo (13-) $18-41 \mathrm{~cm}$, lamina pinnatisecta, inaequilatera, $36-58 \mathrm{~cm}$
\end{abstract}


longa, 31-37 cm lata. Inflorescentia pedunculo (12-) 16.5-19 cm longo, in vivo usque ad $1 \mathrm{~cm}$ (in sicco usque ad $6 \mathrm{~mm}$ ) diam.; spatha cremea $15-23 \mathrm{~cm}$ longa, ca. $4.5 \mathrm{~cm}$ lata; spadice in vivo cremeo, in sicco nigrescente, in vivo $6-13 \mathrm{~cm}$ longo, ca. $2 \mathrm{~cm}$ diam., maturitate in sicco 9-12 cm longo, $1.8-2 \mathrm{~cm}$ diam.; axe in sectione tranversali vinoso vel aurantiaco, ca. $7 \mathrm{~mm}$ diam.

Hemiepiphyte to $10 \mathrm{~m}$ high in trees; juvenile plants with blades petiolate, not shingled; stem drying blackened, closely and acutely ridged; petioles $2-2.5 \mathrm{~cm}$ long, sheathed almost throughout, the margins turned inward, the sheath apex narrowly rounded at least on one side, the free portion sharply sulcate; blades subcoriaceous, narrowly oblong-lanceolate, $5.5-\mathrm{cm}$ long, 5 times longer than wide, drying matte on both surfaces; pre-adult plants with petioles 6.5-9 $\mathrm{cm}$ long, narrowly sheathed almost to the apex; preadult blades narrowly ovatelanceolate $17.5-18.5 \mathrm{~cm}$ long, $21-21 \mathrm{~cm}$ wide, deeply 4-6-lobed, 4.3-6 cm wide, 2.94.2 times longer than wide, pinnately lobed with 1-4 narrow lobes divided to or almost to the base; adult plants with stem assymetrical, to $2 \mathrm{~cm}$ diam.; internodes shorter than broad; petioles (13)18-41 cm long, sheathed to within $8 \mathrm{~cm}$ of base of blade; blades $36-58 \mathrm{~cm}$ long; $31-37 \mathrm{~cm}$ wide; pinnae 7-9 pairs, $17-26 \mathrm{~cm}$ long, $0.6-1.8 \mathrm{~cm}$ wide, 2-6 cm apart, most with a single medial rib, sometimes 2-ribbed, the upper edge ending abruptly on the midrib, the lower margin broadly confluent on the midrib and ending usually near the emergence of the next lower lobe; upper surface drying blackened and matte, minutely papillate; lower surface drying blackish yellow-brown, weakly glossy and only slightly paler; midrib obtusely sunken and concolorous above (drying deeply sunken), drying narrowly and obtusely raised and slightly brownish below; primary lateral veins $2-4$ per side, arising at $15-20^{\circ}$ angle, drying darker than surface, acute to bluntly raised, with numerous whitish linear cellular inclusions; sinus narrowly linear-lanceolate in outline; lateral lobes $2-12 \mathrm{~mm}$ wide, narrowly tapering to an acicular apex, sometimes still weakly connecting to the adjacent segment. Inflorescences 2 per axil; peduncle medium-dark green, (12)16.5-19 $\mathrm{cm}$ long, to $1 \mathrm{~cm}$ diam., to $6 \mathrm{~mm}$ diam. on drying, blackened; spathe creamy white, matte outside, only slightly paler inside, moderately coriaceous, markedly cucullate with the apical portion directed forward and hooding the opening, 15-23 cm long, $4.5 \mathrm{~cm}$ wide at anthesis (flattening to $11 \mathrm{~cm}$ wide), weakly convolute at the base for up to $2.5 \mathrm{~cm}$ with the lateral margins markedly folded and with the apical $1 / 2$ protruding forward at almost a $90^{\circ}$ to the axis of the spathe, acuminate at apex; spadix cylindroid, weakly tapered toward both ends, narrowly rounded at apex, 6-13 cm long, $2 \mathrm{~cm}$ diam., creamy white, deep wine-red to orange in cross-section, drying blackened, 9-12 cm long, 1.8-2 cm diam. at maturity, the axis ca. $7 \mathrm{~mm}$ wide; pistils ca. 7 $\mathrm{mm}$ long, creamy white; style about as broad as the pistil, tapered weakly to a nipple-like stigma; stamens white, held at about $2 / 3$ the length of the pistils; anthers with thecae oblong, closely parallel, ca. $3 \mathrm{~mm}$ long; unripened. Infructescence pale green, sometimes with the old spathe persisting from base, the berries acute at apex.

Paratypes: FRENCH GUIANA. Réserve Naturelle des Nouragues Camp Arataye, a short distance from the mouth of the Arataye River at jct. of the Approuague River, $3^{\circ} 59^{\prime} \mathrm{N}$, $52^{\circ} 35^{\prime} \mathrm{W}$, Poncy 1700 (CAY, P); grounds of the main camp and vic., $100 \mathrm{~m}, 11$ Nov. 2003, Mori et al. 25701 (CAY, MO); along Arataye River, Oct. 1996, Moonen 139 (MO); 264 (MO); 291 (MO).

Monstera barrieri is known only from the type locality in French Guiana. It is characterized by its pinnately lobed, blackishdrying blades with slender pinnae that are narrowly long-tapered toward the apex and not at all constricted toward the base. Also characteristic is the cuculate spathe and the 


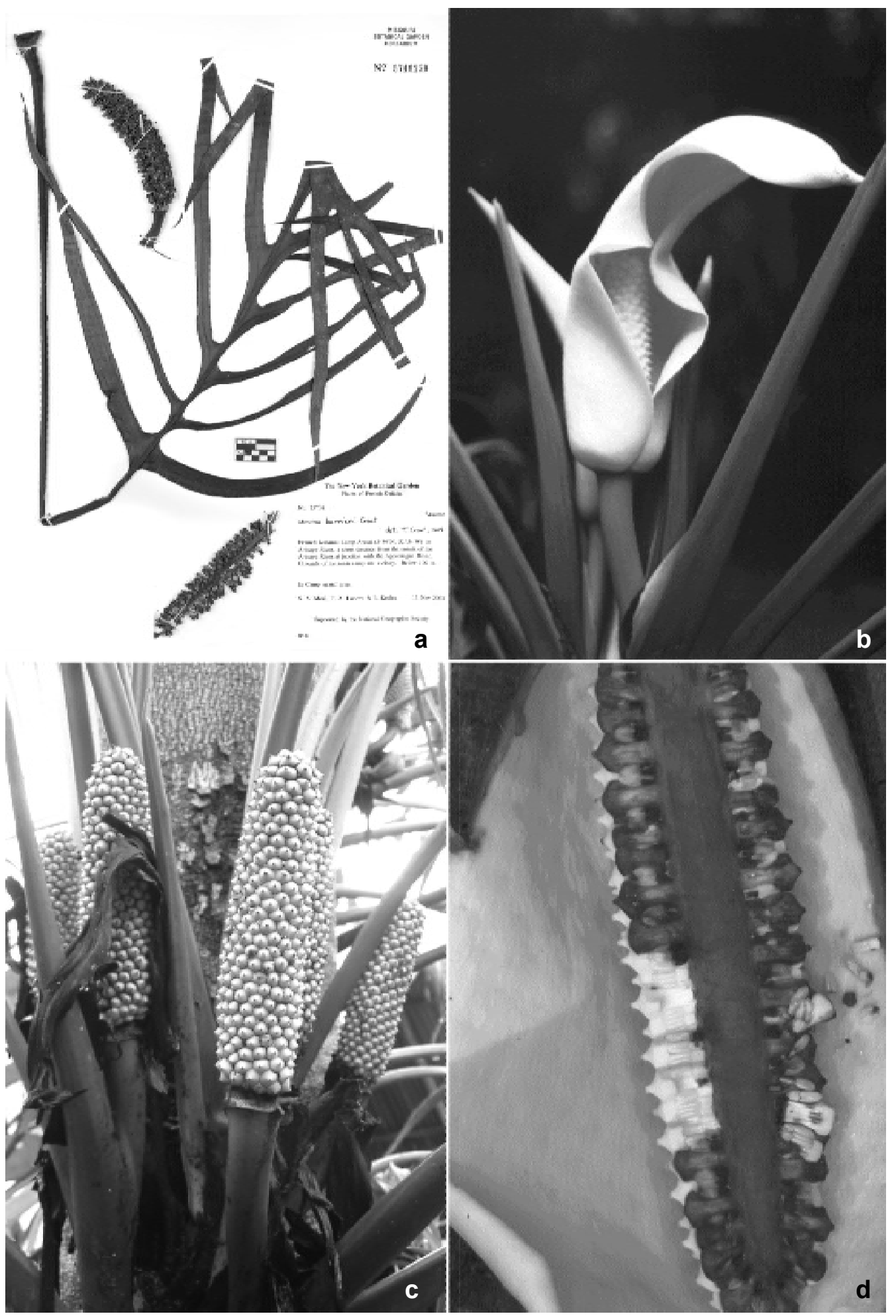

Figure 1 - a-d. Monstera barrieri Croat, Moonen \& Poncy. a. Herbarium specimen showing pinnatifid blades and infructescences. (Mori et al. 25701); b. inflorescence showing cucullate spathe with apical portion directed forward hooding the opening; c. fruiting plant. d. spadix cross-section with spathe in background. (Poncy 1700) Photo by S. Mori. 
bright reddish color of the cross-section of both the spadix and the pistils.

The species is most similar to $M$. expilata Schott in its blackish coloration and texture of the leaves on drying, but that species has blades that are merely perforate, not pinnate and a straight spathe less than $8 \mathrm{~cm}$ long. It is also similar to M. subpinnata (Schott) Engler, a species that has pinnately lobed leaves that also dry black, but that species is restricted to the upper Amazon basin and has up to 12 lobes that are constricted toward the midrib.

\section{ACKnowledgements}

The authors wish to thank Roy Gereau, Missouri Botanical Garden, for the Latin diagnosis and Emily Yates, Missouri Botanical Garden, for editing of the manuscript and preparation of the images and legend. 
